\title{
Pemberian kompres daun kubis (brassica oleracea var. capitata) dengan penurunan nyeri pasien pasca operasi kanker payudara
}

\author{
Djunizar Djamaludin ${ }^{1}$, Hudzaifah Al Fatih², Devi Surya Qaulia ${ }^{3 *}$
}

1Program Studi Ilmu Keperawatan Universitas Malahayati Bandar Lampung. Email: bluenavi01@gmail.com

${ }^{2}$ Fakultas IImu Keperawatan Universitas Bina Sarana Informatika Bandung.

Email: ns_fatih@yahoo.com

${ }^{3}$ Rumah Sakit Umum Daerah Dr. H. Abdul Moeloek Provinsi Lampung. *Email: devinata.1995@gmail.com

\section{Abstract \\ Cabbage leaves (brassica oleracea var. capitata $f$. alba) in patients with post-mastectomy pain}

Background: In patients with breast cancer, chronic pain affects $25 \%$ of $60 \%$ of patients who are undergoing treatment. And around of 5,6 Muscle pain and stiffness are the main complaints of primary breast cancer treatment such as hypersensitivity involving symptoms of neck, armpit and shoulder pain

Purpose: To determine the effect of cold cabbage leaves compresses on pain reduction in patients with post-mastectomy pain

Method: A quantitative by quasi-experiment with one group pretest - posttest design approach. The population were 50 patients who experienced postoperative breast pain, a sample of 17 respondents. The sampling technique by accidental sampling and Statistical tests used the t-test.

Results: The average pain in patients after breast cancer surgery before being given a cold cabbage leaves compresses, with the average pain being at 7.71 points, while the standard deviation of 1.213 . After cold cabbage leaves compresses are given, the average pain is at 7.71 , while the standard deviation is 1.213 . Statistical test results obtained a value of $p=0,000$.

Conclusion: There is an effect of cold cabbage leaves compresses on the reduction of pain in post-breast cancer surgery patients at RSUD Dr. H. Abdul Moeloek Lampung Province in 2019. Suggestions for health workers to be able to provide counseling and good information about the benefits of non-pharmacological treatment in dealing with pain problems in patients who experience pain problems after mastectomy surgery.

\section{Keywords : Cabbage leaves (brassica oleracea var. Capitata f. Alba); Compresses; Patients; Post-mastectomy; Pain}

Pendahuluan: Pada pasien dengan kanker payudara, nyeri kronis mempengaruhi $25 \%$ dari $60 \%$ pasien yang menjalani perawatan. Dan sekitar 5,6 Nyeri otot dan kekakuan merupakan keluhan utama dari pengobatan kanker payudara primer seperti hipersensitivitas yang melibatkan gejala-gejala nyeri leher, ketiak dan bahu.

Tujuan: Untuk mengetahui pengaruh pemberian kompres daun kubis dingin terhadap penurunan nyeri pada pasien pasca operasi kanker payudara

Metode: Penelitian ini adalah kuantitatif dengan desain quasi eksperimental dengan pendekatan one group pretest - posttest. Populasinya adalah pasien yang mengalami nyeri pasca operasi kanker payudara sebanyak 50 orang, sampel sebanyak 17 responden. Teknik sampel menggunakan accidental sampling dan uji statistik menggunakan uji t-tes

Hasil : Rerata nyeri pada pasien pasca operasi kanker payudara sebelum diberikan kompres daun kubis, dengan rerata nyeri berada pada skor 7,71, sedangkan standar deviasi 1,213. Sesudah diberikan kompres daun kubis, dengan rerata nyeri berada pada skor 7,71, sedangkan standar deviasi 1,213. Hasil uji statistik didapatkan nilai $p$ $=0,000$.

Simpulan: Ada pengaruh pemberian kompres daun kubis terhadap penurunan nyeri pasien pasca operasi kanker payudara di RSUD Dr. H. Abdul Moeloek Provinsi Lampung Tahun 2019. Saran bagi petugas kesehatan agar dapat memberikan penyuluhan dan informasi yang baik tentang manfaat pengobatan non farmakologi dalam menangani masalah nyeri pada pasien yang mengalami masalah gangguan nyeri pasca melakukan operasi mastektomi.

Kata Kunci: Kompres dingin; Daun kubis; Nyeri; Pasien; Pasca operasi; Kanker payudara 
Pemberian kompres daun kubis (brassica oleracea var. capitata) dengan penurunan nyeri pasien pasca operasi kanker payudara

\section{PENDAHULUAN}

Kejadian kanker meningkat hingga 2.1 juta kasus baru pada 2018. Kanker payudara sebagai penyebab kematian pada perempuan dan merupakan penyebab kematian kelimasebanyak 627000 kematian (15\%) karena prognosisnya dipercaya sebagai penyebab kematian di Negara-nega berkembang (Lasswell, 2018).

Lebih dari $30 \%$ dari kematian akibat kanker disebabkan oleh lima faktor risiko perilaku dan pola makan, yaitu: (1)Indeks massa tubuh tinggi, (2) kurang konsumsi buah dan sayur, (3) kurang aktivitas fisik, (4) penggunaan rokok, dan (5) konsumsi alkohol berlebihan. Merokok merupakan faktor risiko utama kanker yang menyebabkan terjadinya lebih dari $20 \%$ kematian akibat kanker di dunia dan sekitar $70 \%$ kematian akibat kanker paru di seluruh dunia. Kanker yang menyebabkan infeksi virus seperti virus hepatitis B/hepatitis $C$ dan virus human papilloma berkontribusi terhadap $20 \%$ kematian akibat kanker di negara berpenghasilan rendah dan menengah. Lebih dari $60 \%$ kasus baru dan sekitar $70 \%$ kematian akibat kanker di dunia setiap tahunnya terjadi di Afrika, Asia dan Amerika Tengah dan Selatan. Diperkirakan kasus kanker tahunan akan meningkat dari 14 juta pada 2012 menjadi 22 juta dalam dua dekade berikutnya ).Pada tahun 2013, kejadian kanker payudara di Indonesia berkisar 61.882 penduduk. Prevalensi tertinggi berada pada provinsi Jawa Tengah yaitu sebesar 11.511 penduduk. Pada provinsi Aceh didapatkan 1.869 kasus kanker payudara. Secara nasional prevalensi penyakit kanker pada penduduk semua umur di Indonesia tahun 2013 sebesar 1,4\%o atau diperkirakan sekitar 347.792 orang. Provinsi D.I. Yogyakarta memiliki prevalensi tertinggi untuk penyakit kanker, yaitu sebesar $4,1 \%$. Berdasarkan estimasi jumlah penderita kanker Provinsi Jawa Tengah dan Provinsi Jawa Timur merupakan provinsi dengan estimasi penderita kanker terbanyak, yaitu sekitar 68.638 dan 61.230 orang (Kementerian Kesehatan Republik indonesia, 2016).

Pada penderita kanker payudara, nyeri kronis mempengaruhi $25 \%$ dari $60 \%$ pasien yang sedang mengalami pengobatan.5,6 Nyeri otot dan kekakuan menjadi keluhan utama pengobatan primer kanker payudara. Penelitian sebelumnya pada 42 wanita setelah mendaptkan tindakan bedah menujukkan bahwa penderita tersebut memiliki hipersensitivitas yang melibatkan gejala nyeri leher, ketiak, dan bahu (Bombonati, \& Sgroi, 2011). Pasien kanker payudara mengalami nyeri akibat dari kemoterapi, tindakan medis, ataupun dikarenakan oleh proses metastasis kanker. Beberapa penderita yang mengalami mastektomi atau torakotomi kadang-kadangmengeluh nyeri pada daerah operasinya 1 atau 2 bulan pasca tindakan. Selain itujuga terdapat disestesia pada jaringan parut yang disertai hiperestesia disekelilingnya. Hal ini disebabkan karena adanya kerusakan jaringan, spasme otot, iskemik jaringan yang dapat melepaskan substansi-substansi seperti: katekolamin,prostaglandin dan peningkatan asam laktat yang menimbulkan nyeri (Susworo, 2007; Nasution, 2013).

Penanganan nyeri secara farmakologis dapat diberikan terapi simtomatis untuk mengurangi rasa sakitnya (analgetik) dan obat anti inflamasi (Zakiyah, 2015). Kubis atau kol (Brassica Oleracea Var. Capitata) merupakan sayuran ekonomis yang sangat mudah ditemukan di sekitar kita. Kubis kaya akan fitonutrien dan berbagai vitamin seperti vitamin $A, C, E$, dan kandungan glukosinolate mempunyai aktivitas antikanker (Dalimartha, \& Adrian, 2011). Kubis juga kaya akan kandungan sulfur yang diyakini dapat mengurangi pembengkakan dan peradangan nyeri (Maryunani, 2010).

Penatalaksanaan nyeri selama ini diberikan terapi farmakologi, sedangkan terapi non farmakologi telah diberikan penyuluhan tentang relaksasi dengan pernafasan dan istirahat, namun hasilnya belum maksimal dikarenakan berbagai hal salah satunya adalah tidak ada demonstrasi yang dilaksanakan untuk pasien sehingga pasien sulit untuk menerapkan apa yang sudah diberikan oleh perawat. Melalui terapi relaksasi, seperti memberikan kompres kubis dingin yang dicontohkan langsung dengan demonstrasi, diharapkan penderita bisa melakukan sendiri di rumah. Upaya yang bisa dilakukan terapi non farmakologi pada nyeri antara lain pengaturan lingkungan yang tenang, pengaturan nutrisi yang baik dan relaksasi (Melastuti, \& Avianti, 2015).

Teknik mengurangi nyeri dan pembengkakan payudara dapat dilakukan melalui kompres dingin

Djunizar Djamaludin' Program Studi llmu Keperawatan Universitas Malahayati Bandar Lampung.

Email :bluenavioı@gmail.com

Hudzaifah Al Fatih ${ }^{2}$ Fakultas Ilmu Keperawatan Universitas Bina Sarana Informatika Bandung.

Email: ns_fatih@yahoo.com

Devi Surya Qaulia ${ }^{3}$ Rumah Sakit Umum Daerah Dr. H. Abdul Moeloek Provinsi Lampung.

*Email : devinata.1995@gmail.com 
Pemberian kompres daun kubis (brassica oleracea var. capitata) dengan penurunan nyeri pasien pasca operasi kanker payudara

kubis (Brassica Oleracea Var. Capitata). Kubis diketahui mengandung asam amino metionin yang berfungsi sebagai antibiotic dan kandungan lain seperti sinigrin (Allylisothiocyanate), minyak mustard, magnesium, Oxylate heterosides belerang, hal ini dapat membantu memperlebar pembuluh darah kapiler sehingga meningkatkan aliran darah untuk keluar masuk dari daerah tersebut, sehingga memungkinkan tubuh untuk menyerap kembali cairan yang terbendung dalam payudara tersebut. Selain itu daun kubis juga mengeluarkan gel dingin yang dapat menyerap panas yang ditandai dari klien merasa lebih nyaman dan daun kubis menjadi layu/matang setelah 20-30 menit penempelan (Kurnia, 2018)

Berdasarkan hasil prasurvey yang dilakukan di ruang rekam medik dan ruang perawat RSUD Dr. H. Abdul Moeloek Provinsi Lampung dengan melihat kanker payudara pada tahun 2018 sebanyak 50 orang.Berdasarkan hasil penelitian tersebut dan banyaknya angka kanker peneliti ingin meniliti "pengaruh pemberian kompres daun kubis terhadap penurunan nyeri pada pasien pasca operasi kanker payudara di RSUD Dr. H. Abdul Moeloek Provinsi Lampung Tahun 2019".

\section{METODE PENELITIAN}

Jenis penelitian kuantitatif dengan rancangan menggunakan desain quasi experiment dengan pendekatan one grup pretest - posttest. Penelitian ini sudah lulus kelaikan etik dari Komisi Etik Penelitian Kesehatan (KEPK) Universitas Malahayati dengan no.489/EC/KEP-UNMAL///2019 pada Tanggal 29 Juli 2019 dan dilaksanakan di RSUD Dr.H Abdul Moeloek Provinsi Lampung. Populasinya sebanyak 50 pasien dan sampelnya sebanyak 17 pasien dengan teknik pengambilan sampel menggunakan purposive sampling. Instrument yang digunakan berupa Visual Analog Score (VAS) yang dilakukan untuk mengukur/observasi pasien sebelum dan sesudah diberikan pemberian kompres daun kubis.

Adapun prosedur pelaksanaan intervensi yang dilakukan meliputi: memilih daun kubis yang masih segar yang berwarna hijau diambil secara utuh perlembar. Daun kubis tersebut di cuci dan ditutupkan di semua area payudara yang bengkak dan kulit yang sehat. Tindakan ini berlangsung selama 20-30 menit atau sampai daun kol tersebut layu (Dapat dilakukan di dalam bra dalam posisi menutupi area payudara).

Perlakuan kompres tersebut diberikan 1 hari sebanyak 2 kali selama 4 hari berturut-turut pagi dan siang hari. dan pada hari ke-5 dilakukan pengukuran skala nyeri dengan menggunakan instrument Visual Analog Score (VAS).

\section{HASIL}

Tabel 1. Rerata Nyeri Pada Pasien Sebelum dan Sesudah Diberikan Terapi Kompres Daun Kubis

\begin{tabular}{lcccccc}
\hline Variabel & Frekuensi (n) & Mean & SD & Min-Max & $95 \%$ Cl & $p$ - value \\
\hline $\begin{array}{l}\text { Nyeri } \\
\text { sebelum }\end{array}$ & 17 & 7,71 & 1,213 & $6-9$ & $7,08-8,33$ & 0,002 \\
$\begin{array}{l}\text { Nyeri } \\
\text { sesudah }\end{array}$ & 17 & 5,24 & 1,348 & $3-8$ & $4,54-593$ & \\
\hline
\end{tabular}

Hasil penelitian didapatkan bahwa rerata nyeri pada pasien pasca operasi kanker payudara sebelum diberikan kompres daun kubis, dengan rerata nyeri berada pada skor 7,71, sedangkan standar deviasi 1,213. Sedangkan rerata nyeri pasien pasca operasi kanker payudara sesudah diberikan kompres daun kubis adalah 7,71 , sedangkan standar deviasi 1,213 . sehingga dapat disimpulkan bahwa ada perbedaan rerata nyeri pada pasien post-op kanker payudara sebelum dengan sesudah diberikan kompres daun kubis. Hasil uji statistik didapatkan nilai $p=0,002(\mathrm{p}$ hitung $<\alpha)$. Hasil uji statistik didapatkan nilai $\rho=0,002(p$ hitung $<\alpha)$, artinya pada

\footnotetext{
Djunizar Djamaludin' Program Studi llmu Keperawatan Universitas Malahayati Bandar Lampung.

Email :bluenaviol@gmail.com

Hudzaifah Al Fatih ${ }^{2}$ Fakultas llmu Keperawatan Universitas Bina Sarana Informatika Bandung.

Email: ns_fatih@yahoo.com

Devi Surya Qaulia ${ }^{3}$ Rumah Sakit Umum Daerah Dr. H. Abdul Moeloek Provinsi Lampung.

${ }^{*}$ Email : devinata.1995@gmail.com
} 
Pemberian kompres daun kubis (brassica oleracea var. capitata) dengan penurunan nyeri pasien pasca operasi kanker payudara

$\alpha=5 \%$ dapat diartikan ada pengaruh pemberian kompres daun kubis terhadap penurunan nyeri pasien pasca operasi kanker payudara.

\section{PEMBAHASAN}

\section{Pengaruh Pemberian Kompres Daun Kubis Terhadap Penurunan Nyeri}

Hasil analisis didapatkan rerata nyeri pada pasien pasca operasi kanker payudara sebelum diberikan kompres daun kubis, dengan rerata nyeri berada pada skor 7,71 , sedangkan standar deviasi 1,213 , dengan nilai nyeri terendah 6 dan nilai nyeri tertinggi 9 . Hasil penelitian ini sesuai teori bahwa kanker payudara adalah kanker yang menyerang organ payudara yang terbentuk dari lemak, jaringan ikat, dan ribuan lobules (kelenjar kecil penghasil air susu) sehingga menimbulkan nyeri yang mendalam jika di lakukan pengangkatan sebagian/parsial ataupun total organ tersebut (Anies, 2018).

Pada waktu seseorang wanita melahirkan, Air Susu Ibu (ASI) akan dikirim langsung keputing melalui saluran kecil saat menyusui. Sel-sel dalam tubuh biasanya tumbuh dan berkembang biak secara teratur. Akan tetapi, proses pada tubuh penderita kanker akan berbeda. Proses tersebut berjalan tidak wajar sehingga pertumbuhan dan perkembangan dan perkembang biakan sel-sel menjadi tidak wajar. Nyeri juga karena terjadinya tekanan atau kerusakan jaringan yang mengandung reseptor nyeri dan juga karena tarikan, jepitan atau metastase.Pada kanker payudara terjadi nyeri karena peradangan, nyeri ini karena kerusakan ujung-ujung saraf reseptor akibat adanya peradangan atau terjepit oleh pembengkakan.Sehingga dapat disimpulkan bahwa nyeri yang disebabkan oleh terganggunya serabut saraf receptor nyeri (Anies, 2018).

Hasil penelitian "Pengaruh Teknik Relaksasi Hand Massage Terhadap Nyeri Pada Pasien Kanker Payudara Di Yayasan Kanker Indonesia Surabaya" Hasil penelitian menunjukkan bahwa rerata tingkat nyeri responden sebelum diberikan teknik relaksasi hand massage adalah 5.09, sedangkan reratatingkat nyeri responden sesudah diberikan teknik relaksasi hand massage adalah 3.09. (Fadilah, \& Astuti, 2016).

Menurut peneliti Individu akan berbeda-beda dalam mempersepsikan nyeri apabila nyeri tersebut memberi kesan ancaman, suatu kehilangan hukuman dan tantangan. Misalnya seorang wanita yang yang mengalami operasi pengangkatan payudara/ post op mamae. Nyeri juga karena terjadinya tekanan atau kerusakan jaringan yang mengandung reseptor nyeri dan juga karena tarikan, jepitan atau metastase.Pada kanker payudara terjadi nyeri karena peradangan, nyeri ini karena kerusakan ujung-ujung saraf reseptor akibat adanya peradangan atau terjepit oleh pembengkakan. Sehingga dapat disimpulkan bahwa nyeri yang disebabkan oleh terganggunya serabut saraf receptor nyeri. Nyeri adalah suatu fenomena yang sulit dipahami, kompleks dan bersifat misteri yang mempengaruhi seseorang serta eksistensinya diketahui bila seseorang mengalaminya. Nyeri merupakan pengalaman yang sangat tidak menyenangkan yang dirasakan seseorang terhadap stimulus tertentu dan tidak dapat dibagi kepada orang lain. nyeri adalah pengalaman sensorik dan emosional yang tidak menyenangkan akibat dari kerusakan jaringan yang nyata dan yang potensial (Susiani, 2016). Penelitian sebelumnya di Yayasan Kanker Indonesia Surabaya menunjukkan bahwa rerata tingkat nyeri responden sebelum diberikan teknik relaksasi hand massage adalah 5.09 , sedangkan rerata tingkat nyeri responden sesudah diberikan teknik relaksasi hand massage adalah 3.09. (Aslama, \& Sutrisna, 2019).

Kubis (Brassica Oleracea Var.Capitata) dapat digunakan untuk terapi pembengkakan karena diketahui mengandung asam amino metionin yang berfungsi sebagai antibiotic dan kandungan lain seperti sinigrin (Allylisothiocyanate), minyak mustard, magnesium, Oxylate heterosides belerang, hal ini dapat membantu memperlebar pembuluh darah kapiler sehingga meningkatkan aliran darah untuk keluar masuk dari daerah tersebut, sehingga memungkinkan tubuh untuk menyerap kembali cairan yang terbendung dalam payudara tersebut (Bradley, Maher, \& Boccon-Gibod, 2012).

Selain itu daun kubis juga mengeluarkan gel dingin yang dapat menyerap panas yang ditandai dari klien merasa lebih nyaman dan daun kubis menjadi layu/matang setelah 30 menit

Djunizar Djamaludin' Program Studi llmu Keperawatan Universitas Malahayati Bandar Lampung.

Email :bluenaviol@gmail.com

Hudzaifah Al Fatih ${ }^{2}$ Fakultas llmu Keperawatan Universitas Bina Sarana Informatika Bandung.

Email: ns_fatih@yahoo.com

Devi Surya Qaulia ${ }^{3}$ Rumah Sakit Umum Daerah Dr. H. Abdul Moeloek Provinsi Lampung.

${ }^{*}$ Email : devinata.1995@gmail.com 
Pemberian kompres daun kubis (brassica oleracea var. capitata) dengan penurunan nyeri pasien pasca operasi kanker payudara

penempelan. Di dalam banyak kasus, ilmu pengetahuan tentang obat bahwa anti oksidan alami yang dimiliki oleh daun kubis tidak dapat digandakan di laboratorium sehingga ini yang menjadi alasan bahwa gel yang terbuat dari ekstrak daun kubis kurang efektif untuk mengobati pembengkakan (Apriani, \& Widyastutik, 2018 ).

Beberapa faktor yang dapat menurunkan pembengkakan payudara adalah konsumsi obat-obatan seperti paracetamol, ibuprofen dan lynoral, mengompres dingin, hangat dingin, memerah atau memompa ASI dan melakukan perawatan payudara. Dalam penelitian ini peneliti tidak dapat melakukan pengawasan secara intensif terhadap faktor yang dapat menurunkan atau meningkatkan skala pembengkakan payudara seperti respon fisiologis laktogenesis, dan let down reflect. Rasa dingin dari kompres daun kubis dinilai dapat meredakan ketegangan pada payudara yang bengkak, dan membuat ibu merasa lebih nyaman. Penelitian yang sama di lakukan di kecamatan Bergas dengan hasil penelitian menunjukkan rerata skala pembengkakan sebelum intervensi pada kelompok eksperimen dan kontrol 5,18 dan 5,06, setelah intervensi pada kelompok eksperimen dan kontrol menurun menjadi 2,35 dan 4,88 . Selisih rerata pembengkakan payudara pada kelompok eksperimen dan kontrol 2,83 dan 0,16. Ada pengaruh bermakna pemberian kompres daun kubis dingin terhadap pembengkakan payudara pada ibu postpartum dengan engorgement dengan $p$-value 0,000 ( $\alpha=0,05)$ (Astutik, Aini, \& Yudanari).

Daun kubis dingin ternyata mengandung bahan obat yang dapat mengurangi nyeri dan biasanya kompres daun kubis menunjukkan khasiatnya dalam waktu yang cukup cepat yaitu dalam beberapa jam. Kubis merupakan sayuran ekonomis dan serbaguna yang mudah ditemukan. Selain itu daun kubis juga mengeluarkan gel dingin yang sistim kerjanya memiliki kesamaan dengan kompres dingin yaitu dapat menyerap panas yang ditandai dari klien merasa lebih nyaman dan daun kubis menjadi layu/matang setelah 30 menit penempelan.

Pemberian kompres dingin melalui kompres daun kubis dapat meningkatkan pelepasan endorfin yang memblok transmisi stimulus nyeri dan juga menstimulasi serabut saraf yang memiliki diameter besar a-Beta sehingga menurunkan transmisi impuls nyeri melalui serabut kecil a Delta dan serabut saraf. Mekanisme penurunan nyeri dengan pemberian kompres dingin berdasarkan atas teori gate control. Semakin tinggi kadar endorphin seseorang, semakin ringan rasa nyeri yang dirasakan. Produksi endorphin dapat ditingkatkan melalui stimulasi kulit. Stimulasi kulit meliputi massage, penekanan jari-jari dan pemberian kompres hangat atau dingin

\section{SIMPULAN}

Didapatkan perbedaan nilai observasi yang sangat signifikan pada nyeri pada pasien pasca operasi kanker payudara sebelum dan sesudah diberikan kompres daun kubis. Hasil uji statistik didapatkan nilai $\rho=0,002(p$ hitung $<\alpha)$, artinya pada $\alpha=5 \%$ dapat diartikan ada pengaruh pemberian kompres daun kubis terhadap penurunan nyeri pasien pasca operasi kanker payudara

\section{SARAN}

Sebaiknya petugas kesehatan agar dapat memberikan penyuluhan dan informasi yang baik tentang manfaat pengobatan non farmakologi dalam menangani masalah nyeri pada pasien yang mengalami masalah gangguan nyeri pasca melakukan operasi mastektomi. Kepada masyarakat diharapkan dapat memanfaatkan pekarangan untuk menanam tanaman obat keluarga (TOGA), salah satunya adalah menanam kubis, selain dapat menjadi makanan sehari-hari, daun kubis juga dapat dijadikan alternatif terapi non farmakologi untuk membantu mengurangi nyeri

\section{DAFTAR PUSTAKA}

Anies, A. (2018). Penyakit Degeneratif. Ar-Ruzz Medika: Yogyakarta

Apriani, A., \& Widyastutik, D. (2018). Efektivitas penatalaksanaan kompres daun kubis (brassica oleracea var. Capitata) dan breast care terhadap pembengkakan payudara bagi ibu nifas. Jurnal IImiah Maternal, 2(4).

Djunizar Djamaludin' Program Studi llmu Keperawatan Universitas Malahayati Bandar Lampung.

Email :bluenaviol@gmail.com

Hudzaifah Al Fatih ${ }^{2}$ Fakultas llmu Keperawatan Universitas Bina Sarana Informatika Bandung.

Email: ns_fatih@yahoo.com

Devi Surya Qaulia ${ }^{3}$ Rumah Sakit Umum Daerah Dr. H. Abdul Moeloek Provinsi Lampung.

${ }^{*}$ Email : devinata.1995@gmail.com 
Pemberian kompres daun kubis (brassica oleracea var. capitata) dengan penurunan nyeri pasien pasca operasi kanker payudara

Aslama, A.W., \& Sutrisna, E. M. (2019). Identifikasi Drug Related Problems (DRPs) Kategori Ketidaktepatan Dosis, Kontraindikasi Dan Interaksi Obat Pada Pasien Kanker Payudara Di Instalasi Rawat Inap Rsud Dr. Moewardi Tahun 2018 (Doctoral dissertation, Universitas Muhammadiyah Surakarta).

Astutik, E. Z., Aini, F., \& Yudanari, Y. G.(2015). Pengaruh pemberian kompres daun kubis dingin terhadap skala pembengkakan payudara pada ibu postpartum dengan engorgement di kecamatan Bergas.

Bombonati, A., \& Sgroi, D. C. (2011). The molecular pathology of breast cancer progression. The Journal of pathology, 223(2), 308-318.

Bradley, W., Maher, D., \& Boccon-Gibod, G. (2012). U.S. Patent No. 8,234,387. Washington, DC: U.S. Patent and Trademark Office.

Dalimartha, S., \& Adrian, F. (2011). Khasiat buah dan sayur. Penebar Swadaya Grup.

Dewiani, K., \& Yetti, P. (2018). Pengaruh kompres daun kubis dingin terhadap penurunan intensitas nyeri dan pembengkakan payudara pada ibu postpartum. Jurnal Keperawatan Muhammadiyah Bengkulu, 6(2), 488-493.

Fadilah, P. N., \& Astuti, P. (2016). Pengaruh Teknik Relaksasi Hand Massage Terhadap Nyeri pada Pasien Kanker Payudara di Yayasan Kanker Indonesia Surabaya. Jurnal Ilmiah Kesehatan (Journal of Health Sciences), 9(2).
Kementerian Kesehatan Republik Indonesia. (2016). Bulan Peduli Kanker Payudara. Jakarta: Infodatin.

Lasswell, H. D. (2018). Politics: Who gets what, when, how. Pickle Partners Publishing.

Maryunani, A. (2010). Nyeri dalam persalinan "teknik dan cara penanganannya". Jakarta: Trans info media.

Melastuti, E., \& Avianti, L. U. (2015). Pengaruh Terapi Slow Stroke Back Massage (SSBM) Terhadap Kualitas Tidur Pasien Post Operasi Di Rsi Sultan Agung Semarang. Jurnal IImiah Kesehatan Rustida, 2(1), 159-168.

Nasution, K. (2013). Aplikasi Model Pembelajaran dalam Perspektif Pendekatan Saintifik. Makalah tidak dipublikasikan, Medan, Widyaswara Mandala tanggal, 27.

Susiani, N. A. (2016). Asuhan Keperawatan Pada Keluarga Yang Mengalami Peningkatan Kadar Asam Urat Dalam Darah Dengan Gangguan Rasa Nyaman Nyeri di RW 09 Kelurahan Rawa Badak Utara. Jurnal Kesehatan Keluarga, 8(1), 9-19.

Susworo, R. (2007). Radioterapi: Dasar-dasar radioterapi, Tata laksana Radioterapi penyakit kanker.

Zakiyah, A. (2015). Nyeri: Konsep dan Penatalaksanaan dalam Praktik Keperawatan Berbasis Bukti. Jakarta: Salemba Medika.

Djunizar Djamaludin' Program Studi llmu Keperawatan Universitas Malahayati Bandar Lampung.

Email :bluenaviol@gmail.com

Hudzaifah Al Fatih ${ }^{2}$ Fakultas llmu Keperawatan Universitas Bina Sarana Informatika Bandung.

Email: ns_fatih@yahoo.com

Devi Surya Qaulia ${ }^{3}$ Rumah Sakit Umum Daerah Dr. H. Abdul Moeloek Provinsi Lampung.

${ }^{*}$ Email : devinata.1995@gmail.com 